Valéria de Castilho Palhares'

José Eduardo Corrente"

Beatriz Bojikian Matsubara"I

Departamento de Enfermagem. Faculdade de Medicina de Botucatu. Universidade Estadual Paulista "Júlio de Mesquita Filho". Botucatu, SP, Brasil

Departamento de Estatística. Instituto de Biociências. Universidade Estadual Paulista "Júlio de Mesquita Filho". Botucatu, SP, Brasil

III Departamento de Clínica Médica. Faculdade de Medicina de Botucatu. Universidade Estadual Paulista "Júlio de Mesquita Filho". Botucatu, SP, Brasil

Correspondence:

Valéria de Castilho Palhares

Alameda Antônio Sartor, 430

18607-340 Botucatu, SP, Brasil

E-mail: valeria@fmb.unesp.br

Received: 5/14/2013

Approved: 3/6/2014

Article available from: www.scielo.br/rsp

\section{Association between sleep quality and quality of life in nursing professionals working rotating shifts}

\section{Associação entre qualidade do sono e qualidade de vida de profissionais de enfermagem que trabalham em turnos}

\begin{abstract}
OBJECTIVE: To analyze the association between sleep quality and quality of life of nursing professionals according to their work schedules.

METHODS: A prospective, cross-sectional, observational study was conducted between January and December 2010, with 264 nursing professionals, drawn from 989 subjects at Botucatu General Hospital and stratified by professional category. The Pittsburg Sleep Quality Index and the WHOQOL-bref were administered to evaluate sleep quality and quality of life, respectively. Self-reported demographic data were collected with a standard form. Continuous variables were reported as means and standard deviations, and categorical variables were expressed as proportions. Associations were evaluated using Spearman's correlation coefficient. The association of night-shift work and gender with sleep disturbance was evaluated by logistic regression analysis using a model adjusted for age and considering sleep disturbance the dependent variable. The level of significance was $\mathrm{p}<0.05$.
\end{abstract}

RESULTS: Night-shift work was associated with severe worsening of at least one component of sleep quality in the model adjusted for age $(\mathrm{OR}=1.91$; $95 \%$ CI 1.04;3.50; $\mathrm{p}=0.036$ ). Female gender was associated with sleep disturbance $(\mathrm{OR}=3.40 ; 95 \% \mathrm{CI} 1.37 ; 8.40 ; \mathrm{p}=0.008)$. Quality of life and quality of sleep were closely correlated $(\mathrm{R}=-0.56 ; \mathrm{p}<0.001)$.

CONCLUSIONS: Characteristics of the nursing profession affect sleep quality and quality of life, and these two variables are associated.

DESCRIPTORS: Nursing, Team. Sleep. Sleep Deprivation, epidemiology. Quality of Life. Shift Work. Cross-Sectional Studies. 


\section{RESUMO}

OBJETIVO: Analisar a associação entre a qualidade do sono e a qualidade de vida dos profissionais de enfermagem segundo organização do trabalho.

MÉTODOS: Estudo transversal, observacional e prospectivo, com 264 profissionais de enfermagem em Botucatu, SP, entre janeiro e dezembro de 2010. Os sujeitos foram sorteados entre os 989 indivíduos que trabalhavam no Hospital Geral de Botucatu e estratificados por categoria profissional. O Índice de Qualidade de Sono de Pittsburgh e o WHOQOL-bref foram aplicados para avaliar qualidade do sono e qualidade de vida, respectivamente. Os dados demográficos foram coletados por meio de formulário padrão. Variáveis contínuas foram apresentadas como média e desvio padrão e variáveis categóricas, como proporções. As associações foram avaliadas por meio do coeficiente de correlação de Spearman. As associações entre turno e sexo com a qualidade do sono foram analisadas por meio de regressão logística, no modelo corrigido para idade. Distúrbio do sono foi a variável dependente. O nível de significância adotado foi $\mathrm{p}<0,05$.

RESULTADOS: Trabalho noturno foi associado com prejuízo importante de pelo menos um componente da qualidade do sono (OR = 1,91; IC95\% 1,04;3,50, $\mathrm{p}=0,036)$. O prejuízo da qualidade do sono também se associou com o sexo feminino (OR = 3,40; IC95\% 1,37;8,40; $p=0,008)$. Houve correlação estreita entre a qualidade de vida e qualidade do sono $(\mathrm{r}=-0,56, \mathrm{p}<0,001)$.

CONCLUSÕES: Características próprias da profissão de enfermagem podem afetar a qualidade do sono e a qualidade de vida, e essas duas variáveis estão associadas entre si.

DESCRITORES: Equipe de Enfermagem. Sono. Privação do Sono, epidemiologia. Qualidade de Vida. Trabalho em Turnos. Estudos Transversais.

\section{INTRODUCTION}

As an important biological function, sleep plays a role in various physiological processes of organisms. ${ }^{9}$ Restful sleep provides the basis for physical, mental, and psychological well-being in humans, and sleep deprivation is associated with less productive behavior. ${ }^{14}$

Some career characteristics that are difficult to modify might pose a disadvantage to professionals. Professions that involve shift work without adequate hours of rest can disrupt the circadian rhythm of the sleep-wake cycle and compromise sleep quality. ${ }^{1}$ The nursing personnel of hospitals with a shift-work system might present sleep disorders related to the characteristics of nursing. Nursing requires attention and often involves activities with a high level of difficulty and responsibility. Factors such as fast pace, excessive working hours, and shift work can lead to occupational stress. ${ }^{1}$ Buysse et $\mathrm{al}^{4}$ proposed a self-administered questionnaire, the Pittsburg Sleep Quality Index (PSQI), for assessing levels of sleep quality. Sleep loss affects performance of cognitive skills, e.g., memory, learning, logical reasoning, mathematical calculations, recognition patterns, complex verbal processing, and decision-making. ${ }^{4}$ Rocha \& De Matino ${ }^{19}$ reported that shift work related sleep disorders caused significant changes in individuals' physical, occupational, cognitive, and social functioning, which also decreased their quality of life (QOL). ${ }^{19}$

Quality of life is a difficult concept to define, and there is still no consensus despite ongoing debate over the past few decades. ${ }^{21}$ However, a subjective and multidimensional approach, including physical and psychological health and social relations, is needed for quality of life assessment. ${ }^{5}$

Awareness of the need to assess individuals' QOL, particularly in the health sector, is growing. ${ }^{21}$ The World Health Organization (WHO) defines quality of life as "an individual's perception of their position in life in the context of culture and value systems in which they live and in relation to their goals, expectations, standards 
and concerns". Workplace health is the main determinant of employees' quality of life. ${ }^{24}$

Developed by different entities, standardized questionnaires are designed to evaluate individuals' quality of life by recognizing its multidimensional nature and emphasizing personal perceptions of it. Specifically, the World Health Organization Quality of Life Assessment Instrument (WHOQOL) is comprised of four domains or factors divided into 24 facets: (i) physical (individual's perception of physical condition); (ii) psychological (individual's perception of affective and cognitive condition); (iii) social (individual's perception of social relations and social roles adopted in life); and (iv) environment (individual's perception of aspects related to the living environment). ${ }^{5} \mathrm{~A}$ short version (WHOQOLbref) consists of 26 questions, two general items of quality of life and 24 questions representing each of the 24 facets of the original instrument. This questionnaire was adapted to the Brazilian context by Fleck. ${ }^{10}$

Night-shift work influences the quality of sleep. ${ }^{8}$ However, the effect of sleep disturbances on quality of life remains to be determined. This study analyzes the association between sleep quality and quality of life of nursing professionals according to work schedules.

\section{METHODS}

A prospective, cross-sectional, observational study was conducted at a general hospital in Botucatu, SP, Southeastern Brazil, in January and December 2010. The sample was selected from a population of 989 employees, including 182 nurses, 222 nurse technicians, and 285 nursing assistants, working at the Hospital das Clínicas da Faculdade de Medicina de Botucatu (University Hospital of the Botucatu Medical School). The work schedules followed a 24-hour rotation system divided into three periods: morning (7:00 am to 4:00 pm), evening (2:00 pm to $11: 00 \mathrm{pm})$, and night (11:00 pm to 7:00 am). Personnel changes during these periods were random and depended on the hospital and the workers' needs. The 989 nursing professionals were distributed across the hospital and assigned to, among others, the following units to provide nursing care: outpatient clinics, wards, laboratories, intensive care units, surgical center, material and sterilization center, post-anesthesia recovery ward, hemodialysis unit, and school health center. The sample size was calculated considering 989 nursing professionals stratified by professional category and adopting an $\alpha=5.0 \%$ and a PSQI score $>5$ in $20.0 \%$ of this population. The estimated sample size was 250 participants, including 46 nurses, 146 nursing assistants, and 58 nurse technicians.

The participants were first selected by drawing lots and then were included after agreeing to participate. The exclusion criteria were pregnancy and absence from work $\geq 4$ weeks at the time of inclusion. Participants who had not adequately completed the questionnaires at the end of data collection were excluded from the analyses. Only those who responded to all 12 questions of the PSQI $(n=226)$ were considered for calculation of the global score.

Data were collected using the PSQI for evaluation of sleep quality, the WHOQOL-bref for the quality of life assessment, and a standard form for collecting demographic data. The PSQI has been validated for the Brazilian population and consists of seven components: (1) subjective sleep quality (individual's perception of sleep quality); (2) sleep latency; (3) sleep duration as the ratio between time slept and time in bed, not necessarily sleeping; (4) habitual sleep efficiency; (5) sleep disturbances (presence of situations that compromise hours of sleep); (6) use of sleep medication; (7) daytime dysfunction (changes in disposition and enthusiasm to perform routine activities). ${ }^{4}$ The global score is calculated as the sum of scores obtained for each of the seven components. Each component is scored from 0 to 3 (the negative extreme on a Likert-type scale) with the same weight. The global score ranges from 0 to 21 ( $\leq 5$ : good sleep quality; $>5$ : poor sleep quality ${ }^{4} \geq 15$ : important sleep impairment).

Quality of life scores were calculated based on the responses in the WHOQOL-bref, ${ }^{10}$ a self-assessment instrument that considers the last two weeks experienced by the subject. The questionnaire consists of four domains: (i) physical (seven questions: evaluates pain, discomfort, energy, fatigue, sleep, mobility, dependence on medications or treatments, and working capacity); (ii) psychological (six questions: evaluates negative and positive feelings, memory, and self-esteem); (iii) social (three questions: evaluates social support, sexual activity, and personal relations); and (iv) environment (eight questions: evaluates physical safety and security, home environment, financial resources, participation in recreational and leisure activities, physical environment (pollution, noise, climate, transport, and transit), opportunity to acquire new information, and skills). Each item is rated on a 5-point Likert-type scale. Domain scores range from 0 (the lowest quality of life) to 100 (the highest quality of life). ${ }^{10}$

The self-administered questionnaires were delivered by the researcher to the nurses. The variables studied were: education level (elementary school; high school; higher education), professional category (nursing assistant, nurse technician, and nurse), overtime (yes; no), work shift (morning; evening; night), and other jobs (yes; no).

Continuous variables are expressed as means, and respective standard deviations and categorical variables are expressed as proportions. The association between quality of life and sleep quality scores was evaluated using Spearman's correlation coefficient. The association of night-shift work and gender with sleep disturbance was evaluated by logistic regression analysis 
using a model adjusted for age and considering severe disturbance in at least one of the PSQI components as the dependent variable. A level of significance of $\mathrm{p}<0.05$ was adopted for all tests.

The study was approved by the Research Ethics Committee of the Faculdade de Medicina de Botucatu of the Universidade Estadual Paulista "Júlio de Mesquita Filho" (Protocol 3422/2010). All participants signed the informed consent form.

\section{RESULTS}

This study included 264 nursing professionals stratified proportionally into three categories: 52 nurses, 60 practical nurses, and 152 nurse technicians. There was a high proportion of women $(87.0 \%)$, and the mean age was 40.4 years (standard deviation - SD: 10.2 years). At the time of evaluation, $12.0 \%$ of the participants worked 30 hours per week and $88.0 \%$ worked 40 hours per week; $77.0 \%$ worked day shifts, $23.0 \%$ worked night shifts, $43.0 \%$ worked overtime, and $14.0 \%$ had two jobs (Table 1); $65.2 \%$ of the professionals had a high school degree, $37.7 \%$ had a bachelor's degree, and $3.1 \%$ had less than a high school degree.
$1.05 ; 3.50 ; \mathrm{p}=0.036)$. Night-shift work was associated with poor sleep efficiency $(\mathrm{R}=0.29 ; \mathrm{p}<0.001)$ and sleep duration $(p=0.002)$. No significant association was observed between having another job and sleep quality.

The lowest score in the WHOQOL-bref was for the environmental domain (57.6; SD: 14.0), and the highest was for the social relations domain $(66.7 ; \mathrm{SD}=18.9)$. The scores for the physical and psychological domains were $66.3(\mathrm{SD}=17.3)$ and $65.2(\mathrm{SD}=16.3)$, respectively (Table 2$)$.

Quality of life was unaffected by gender, whereas age slightly influenced the physical domain $(\mathrm{R}=-0.14$; $\mathrm{p}=0.019)$. A higher education level was associated with better environmental domain scores $(\mathrm{R}=0.24$; $\mathrm{p}<0.001)$. WHOQOL-bref scores were unaffected by night-shift work, whereas overtime affected environmental domain scores $(\mathrm{R}=0.18 ; \mathrm{p}=0.003)$ (Table 3). There was association between working hours of professionals and the social domain, and between overtime and the environmental domain. Education level also influenced quality of life, but no significant association was observed for the other variables.

A correlation was observed between the sleep quality and the quality of life domains $(r=-0,56 ; p<0.001)$ (Table 4).

Table 1. Demographic data. Botucatu, SP, Southeastern Brazil, January and December 2010.

\begin{tabular}{lcccc}
\hline Variable & $\begin{array}{c}\text { Nurse } \\
(\mathrm{N}=52)\end{array}$ & $\begin{array}{c}\text { Nursing assistant } \\
(\mathrm{N}=60)\end{array}$ & $\begin{array}{c}\text { Nurse technician } \\
(\mathrm{N}=152)\end{array}$ & $\begin{array}{c}\text { Total } \\
(\mathrm{N}=264)\end{array}$ \\
\hline Age (years) & $36.9(10.0)$ & $33.1(7.9)$ & $44.5(9.1)$ & $40.4(10.2)$ \\
Gender (Male/Female) & $4 / 48$ & $2 / 58$ & $29 / 123$ & $35 / 229$ \\
Overtime (Yes/No/NI) & $5 / 47 / 0$ & $28 / 32 / 0$ & $80 / 70 / 2$ & $113 / 149 / 0$ \\
Working hours (30h/40h/NI) & $6 / 45 / 1$ & $2 / 58 / 0$ & $22 / 125 / 5$ & $30 / 228 / 6$ \\
Shift (Day/Night/NI) & $44 / 7 / 1$ & $34 / 26 / 0$ & $121 / 27 / 4$ & $199 / 60 / 5$ \\
Other jobs (Yes/No/NI) & $8 / 44 / 0$ & $14 / 46 / 0$ & $16 / 135 / 1$ & $38 / 225 / 1$ \\
\hline
\end{tabular}

$\mathrm{NI}$ : not informed

${ }^{\text {a }}$ Presented as mean (standard deviation).

Figure shows the sleep quality scores for the seven PSQI components and the global score. The mean PSQI score was $7.3(\mathrm{SD}=3.6)$. The global PSQI score ranged from 0 to 17 and was $\leq 5$ in $34.9 \%$ of the participants. The remaining $65.1 \%$ presented some degree of sleep disturbance; $4.1 \%$ of subjects exhibited important impairment (score $\geq 15$ ) (Figure).

Age and low education level negatively influenced sleep quality. Female professionals scored higher than males in all sleep components, except for sleep latency. Female gender more than tripled the chance of severe disturbance in at least one component $(\mathrm{OR}=3.40 ; 95 \% \mathrm{CI} 1.37 ; 8.40$; $\mathrm{p}=0.008)$ in the model adjusted for age and night-shift work. Night-shift work almost doubled the risk of severe worsening of at least one sleep quality component in the regression model adjusted for age $(\mathrm{OR}=1.91 ; 95 \% \mathrm{CI}$

\section{DISCUSSION}

The present study evaluated sleep quality and quality of life in nursing professionals working in shifts. In this population, we found a significant association between sleep quality and quality of life. These variables were also influenced by both demographic and work characteristics.

The predominance of women aligns with the literature and shows a trend towards feminization of the healthcare workforce. These data reaffirm that, historically, patient care, including typical activities such as assisting, bathing and feeding, was always delegated to women, in agreement with the social division of labor. ${ }^{15}$ 


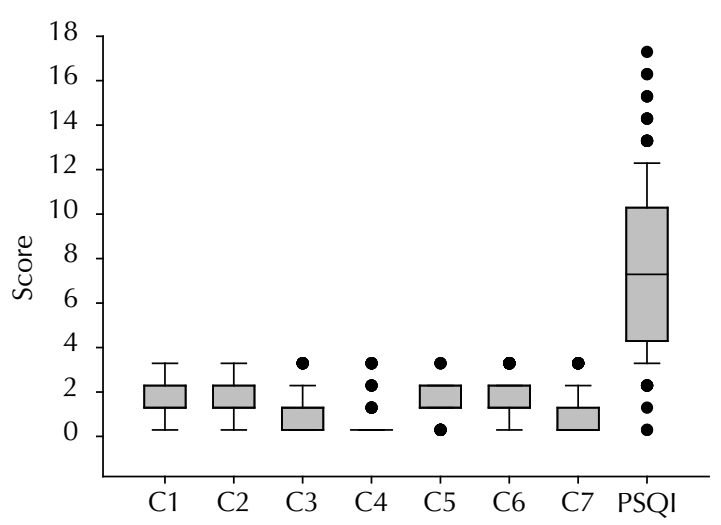

Components of Sleep Quality and PSQI

C1: Subjective sleep quality; C2: Sleep latency; C3: Sleep duration; C4: Habitual sleep efficiency; C5: Sleep disturbances; C6: Use of sleep medication; C7: Daytime dysfunction; PSQI: Global score

Figure. Sleep quality components scores and global Pittsburg Sleep Quality Index (PSQI) score. Botucatu, SP, Southeastern Brazil, January and December 2010.
In this study, the participants' current lifestyle is somehow negatively associated with sleep quality. The causes of this association cannot be defined based on the present results and were not this study's objective.

Working night shifts or weekends entails changes in the temporal distribution of individual activities and alters nocturnal sleeping patterns. ${ }^{23}$ Shift workers experience an essentially different daily life than the remaining community in terms of the temporal distribution of their activities. Work performed at night or on weekends affects the social life that, otherwise, typically consists of nocturnal sleep, daytime work, and leisure time after work and on weekends. Distinct aspects of social and family life can facilitate or hinder overall daily life and are important factors in the process of tolerance to the work regimen. ${ }^{13}$ Despite these considerations, working night shifts was not associated with impaired sleep quality when compared to other shifts. In other words, factors other than work shift influence sleep quality.

For example, age and lower education level negatively influenced quality of sleep, in accordance with other

Table 2. WHOQOL-bref domain scores. Botucatu, SP, Southeastern Brazil, January and December 2010.

\begin{tabular}{lcccccc}
\hline Variable & $\mathrm{N}$ & Mean $(\mathrm{SD})$ & $\mathrm{SD}$ & Minimum & Maximum & Median \\
\hline Physical & 258 & 66.3 & 17.34 & 3.57 & 100 & 69.6 \\
Psychological & 253 & 65.2 & 16.3 & 8.33 & 100 & 66.7 \\
Social relations & 257 & 66.7 & 18.94 & 0 & 100 & 75.0 \\
Environment & 257 & 57.6 & 14.0 & 12.50 & 100 & 59.4 \\
\hline
\end{tabular}

SD: standard deviation

The mean age of approximately 40 years also accords with other studies reporting an age range of 23 to 44 years (mean of 34 years) for these professionals. ${ }^{6}$

The nurses presented the typical $40 \mathrm{~h}$ work week, as also reported by other investigators evaluating quality of life in similar populations. ${ }^{8,23}$ Almost half the participants reported working overtime, and $14.0 \%$ had a second job. As a consequence, the nurses remained in the work environment for long periods, supporting the influence of working conditions on quality of life. Working night shifts, observed in $25.0 \%$ of the sample, is common in the nursing profession. Shift work is needed in healthcare because of round-the-clock activities, and an excessive proportion of these professionals work night shifts. ${ }^{25}$

The frequency of impaired sleep quality was high in this population $(65.1 \%)$, similar to populations working in other hospitals in Brazil and other countries, ${ }^{22}$ but similar results have been reported for other occupations. ${ }^{12}$ The mean PSQI score in the present study was similar to those in studies with orchestra musicians. ${ }^{17}$ authors. ${ }^{16}$ No consensus exists regarding the underlying cause of the association between lower education level and impaired sleep quality. However, female gender tripled the risk of impairment of sleep components, and a higher prevalence of insomnia or poor sleep quality has been observed in women. ${ }^{2}$ Investments in the professional qualifications of workers may have beneficial effects on sleep quality and on other aspects of productive life.

The environmental domain relates to the work environment, type of stressful job, hierarchical submission, and distress in response to the physical and emotional fragility of the patients. ${ }^{21,24}$ These results were comparable to studies that evaluated similar populations. ${ }^{18}$ Lack of satisfaction with work is indicated as a cause of decreased professional performance in nursing. ${ }^{20}$

The present study showed an association between the working hours of professionals and the social domain, and between overtime and the environmental domain. The psychological stress generated in the work environment and its repercussions on quality of life have been a matter of discussion in the literature. ${ }^{25}$ Contemporary 
Table 3. Correlation between quality of life domains and demographic variables (Spearman's correlation coefficient). Botucatu, SP, Southeastern Brazil, January and December 2010.

\begin{tabular}{|c|c|c|c|c|c|}
\hline Variable & & Physical & Psychological & Social & Environmental \\
\hline Working hours (30h/40h) & $\begin{array}{c}\text { Coefficient } \\
\mathrm{p} \\
\mathrm{n}\end{array}$ & $\begin{array}{c}-0.03 \\
0.6358 \\
252\end{array}$ & $\begin{array}{c}-0.02 \\
0.7178 \\
247\end{array}$ & $\begin{array}{c}-0.12 \\
0.0481 \\
251\end{array}$ & $\begin{array}{c}-0.08 \\
0.1904 \\
251\end{array}$ \\
\hline Overtime (Yes/No) & $\begin{array}{c}\text { Coefficient } \\
\mathrm{p} \\
\mathrm{n}\end{array}$ & $\begin{array}{c}-0.02 \\
0.6872 \\
256\end{array}$ & $\begin{array}{c}-0.04 \\
0.5546 \\
251\end{array}$ & $\begin{array}{c}0.04 \\
0.5634 \\
255\end{array}$ & $\begin{array}{c}0.18 \\
0.0037 \\
255\end{array}$ \\
\hline Age (Years) & $\begin{array}{c}\text { Coefficient } \\
\mathrm{p} \\
\mathrm{n}\end{array}$ & $\begin{array}{c}-0.14 \\
0.0194 \\
258\end{array}$ & $\begin{array}{c}0.01 \\
0.8655 \\
253\end{array}$ & $\begin{array}{c}-0.004 \\
0.9540 \\
257\end{array}$ & $\begin{array}{c}-0.03 \\
0.6484 \\
257\end{array}$ \\
\hline Gender (Male/Female) & $\begin{array}{c}\text { Coefficient } \\
\mathrm{p} \\
\mathrm{n}\end{array}$ & $\begin{array}{c}-0.11 \\
0.0826 \\
258\end{array}$ & $\begin{array}{c}-0.07 \\
0.2393 \\
253\end{array}$ & $\begin{array}{c}-0.04 \\
0.4765 \\
257\end{array}$ & $\begin{array}{c}0.01 \\
0.8613 \\
257\end{array}$ \\
\hline Shift (Morning/Night/Other) & $\begin{array}{c}\text { Coefficient } \\
\mathrm{p} \\
\mathrm{n}\end{array}$ & $\begin{array}{c}0.03 \\
0.5933 \\
253\end{array}$ & $\begin{array}{c}0.07 \\
0.2358 \\
248\end{array}$ & $\begin{array}{c}-0.006 \\
0.9189 \\
252\end{array}$ & $\begin{array}{c}-0.06 \\
0.3004 \\
252\end{array}$ \\
\hline Other jobs (Yes/No) & $\begin{array}{c}\text { Coefficient } \\
\mathrm{p} \\
\mathrm{n}\end{array}$ & $\begin{array}{c}-0.07 \\
0.2253 \\
257\end{array}$ & $\begin{array}{c}-0.02 \\
0.6935 \\
252\end{array}$ & $\begin{array}{c}-0.05 \\
0.4389 \\
256\end{array}$ & $\begin{array}{c}-0.004 \\
0.9409 \\
256\end{array}$ \\
\hline $\begin{array}{l}\text { Education level } \\
\text { (Elementary/High school/ } \\
\text { Higher education) }\end{array}$ & $\begin{array}{c}\text { Coefficient } \\
\mathrm{p} \\
\mathrm{n}\end{array}$ & $\begin{array}{c}0.13 \\
0.0338 \\
253\end{array}$ & $\begin{array}{c}0.08 \\
0.2230 \\
248\end{array}$ & $\begin{array}{c}0.11 \\
0.0908 \\
252\end{array}$ & $\begin{array}{c}0.24 \\
<0.0001 \\
252\end{array}$ \\
\hline $\begin{array}{l}\text { Professional category } \\
\text { (Nurse/Nurse technician/ } \\
\text { Assistant) }\end{array}$ & $\begin{array}{c}\text { Coefficient } \\
\mathrm{p} \\
\mathrm{n}\end{array}$ & $\begin{array}{c}-0.12 \\
0.0752 \\
258\end{array}$ & $\begin{array}{c}-0.02 \\
0.7755 \\
253\end{array}$ & $\begin{array}{c}-0.07 \\
0.2678 \\
257\end{array}$ & $\begin{array}{c}-0.15 \\
0.0178 \\
257\end{array}$ \\
\hline
\end{tabular}

Values with statistical significance are shown in bold.

Table 4. Correlation between WHOQOL-bref domains and quality of sleep variables (Spearman's correlation coefficient). Botucatu, SP, Southeastern Brazil, January and December 2010.

\begin{tabular}{|c|c|c|c|c|c|}
\hline Variable & & Physical & Psychological & Social & Environment \\
\hline C1: Subjective sleep quality & $\begin{array}{c}\text { Coefficient } \\
\mathrm{p} \\
\mathrm{n}\end{array}$ & $\begin{array}{c}-0.52 \\
<0.0001 \\
258\end{array}$ & $\begin{array}{c}-0.53 \\
<0.0001 \\
253\end{array}$ & $\begin{aligned} &-0.28 \\
&< 0.0001 \\
& 257\end{aligned}$ & $\begin{array}{c}-0.27 \\
<0.0001 \\
257\end{array}$ \\
\hline C2: Sleep latency & $\begin{array}{c}\text { Coefficient } \\
\mathrm{p} \\
\mathrm{n}\end{array}$ & $\begin{array}{c}-0.37 \\
<0.0001 \\
245\end{array}$ & $\begin{array}{c}-0.35 \\
<0.0001 \\
240\end{array}$ & $\begin{array}{c}-0.23 \\
0.0003 \\
244\end{array}$ & $\begin{array}{c}-0.27 \\
<0.0001 \\
244\end{array}$ \\
\hline C3: Sleep duration & $\begin{array}{c}\text { Coefficient } \\
\mathrm{p} \\
\mathrm{n}\end{array}$ & $\begin{array}{c}-0.27 \\
<0.0001 \\
248\end{array}$ & $\begin{array}{c}-0.18 \\
0.0042 \\
243\end{array}$ & $\begin{array}{c}-0.12 \\
0.0553 \\
248\end{array}$ & $\begin{array}{c}-0.14 \\
0.0265 \\
247\end{array}$ \\
\hline C4: Habitual sleep efficiency & $\begin{array}{c}\text { Coefficient } \\
\mathrm{p} \\
\mathrm{n}\end{array}$ & $\begin{array}{c}0.06 \\
0.3322 \\
238\end{array}$ & $\begin{array}{c}0.08 \\
0.2218 \\
234\end{array}$ & $\begin{array}{c}0.01 \\
0.8643 \\
238\end{array}$ & $\begin{array}{c}-0.006 \\
0.9164 \\
237\end{array}$ \\
\hline C5: Sleep disturbances & $\begin{array}{c}\text { Coefficient } \\
\mathrm{p} \\
\mathrm{n}\end{array}$ & $\begin{array}{c}-0.44 \\
<0.0001 \\
249\end{array}$ & $\begin{array}{c}-0.32 \\
<0.0001 \\
245\end{array}$ & $\begin{array}{c}-0.19 \\
0.0028 \\
249\end{array}$ & $\begin{array}{c}-0.24 \\
<0.0001 \\
248\end{array}$ \\
\hline C6: Use of sleep medication & $\begin{array}{c}\text { Coefficient } \\
\mathrm{p} \\
\mathrm{n}\end{array}$ & $\begin{array}{c}-0.56 \\
<0.0001 \\
258\end{array}$ & $\begin{array}{c}-0.43 \\
<0.0001 \\
253\end{array}$ & $\begin{array}{c}-0.30 \\
<0.0001 \\
257\end{array}$ & $\begin{array}{c}-0.37 \\
<0.0001 \\
257\end{array}$ \\
\hline C7: Daytime dysfunction & $\begin{array}{c}\text { Coefficient } \\
\mathrm{p} \\
\mathrm{n}\end{array}$ & $\begin{array}{c}-0.44 \\
<0.0001 \\
256\end{array}$ & $\begin{array}{c}-0.39 \\
<0.0001 \\
252\end{array}$ & $\begin{array}{c}-0.25 \\
0.0002 \\
255\end{array}$ & $\begin{array}{c}-0.17 \\
0.0072 \\
256\end{array}$ \\
\hline PSQI: Global score & $\begin{array}{c}\text { Coefficient } \\
\mathrm{p} \\
\mathrm{n}\end{array}$ & $\begin{array}{c}-0.56 \\
<0.0001 \\
221\end{array}$ & $\begin{array}{c}-0.51 \\
<0.0001 \\
219\end{array}$ & $\begin{array}{c}-0.28 \\
<0.0001 \\
221\end{array}$ & $\begin{array}{c}-0.35 \\
<0.0001 \\
221\end{array}$ \\
\hline
\end{tabular}

Values with statistical significance are shown in bold. 
society increasingly demands uninterrupted services, and this is particularly evident in the healthcare sector. Workers are therefore exposed to a number of healthdisturbing factors such as alterations in biological rhythms, sleep disturbances, and cardiovascular, gastrointestinal, and psychological disorders, which result in discomfort, restrict social and family life, and potentiate diseases. These factors establish a complex relationship between work, quality of life, and working capacity. ${ }^{7}$

Nursing at hospitals is one of the most widely studied professions, with shift work appearing as a stressor. A significant percentage of individuals reports disturbances, particularly physical disorders. ${ }^{11}$ However, no such association was observed in the present study. The small number of nurses who worked night shifts might explain this finding.

Education level also influenced quality of life. This effect has also been reported by other authors investigating different populations. ${ }^{18}$ Workers with lower education levels who face complex situations, especially in a large hospital, experience mental stress during their working time.

Older age and a higher household income had a positive impact on the physical and environmental domains in a study evaluating the QOL of practical nurses. ${ }^{18}$ Undergraduate professional nurses were older and had lower incomes in the present investigation. This factor may have influenced the quality of life of the population

\section{REFERENCES}

1. Admi H, Tzischinsky O, Epstein R, Herer P, Lavie P. Shift work in nursing: is it really a risk factor for nurses' health and patients' safety? Nurs Econ. 2008;26(4):250-7.

2. Baker FC, Kahan TL, Trinder J, Colrain IM. Sleep quality and sleep electroencephalogram in women with severe premenstrual syndrome. Sleep. 2007;30(10):1283-91 .

3. Braga LC, Carvalho LR, Binder MCP. Condições de trabalho e transtornos mentais comuns em trabalhadores da rede básica de saúde de Botucatu (SP). Cienc Saude Coletiva. 2010;15(Suppl 1):1585-96. DOI: 10.1590/ S1413-8123201000070007049891999001100007

4. Buysse DJ, Reynolds CF 3rd, Monk TH, Berman SR, Kupfer DJ. The Pittsburg Sleep Quality Index: a new instrument for psychiatric practice and research. Psychiatry Res. 1989;28(2):193-213. DOI:10.1016/0165-1781(89)90047-4

5. Carr AJ, Gibson B, Robinson PG. Measuring quality of life: is quality of life determined by expectations or experience? BMJ. 2001;322(7296):1240-3. DOI:10.1136/bmj.322.7296.1240

6. Chaves EC. Jornada noturna: recursos para minimizar os prejuízos. Nursing (São Paulo). 2000;24(3):6-7. studied, but the results do not permit any conclusion. Other factors related to work organization might influence the quality of life in nursing professions. ${ }^{3}$ These results highlight the multifactorial concept of quality of life and suggest that many variables interfere with WHOQOL scores. No conclusion as to which variables are involved can be drawn in the present study. However, our results suggest a statistically significant association between the quality of life domains and the demographic and professional variables of these subjects.

Considering the role of sleep in individuals' lives and the harmful effects of sleep deprivation, we can state that an inadequate level of sleep has direct repercussions on quality of life, causing social isolation, anxiety, and low self-esteem, in addition to several physical symptoms. ${ }^{13}$ Sleep quality and quality of life are intimately related. Our results support this concept, showing that sleep alterations were consistently associated with impaired quality of life. Sleep quality, which also has a multifactorial basis, presented weak, but significant, correlation with quality of life. This result should be reported since it was found in a population that has been little studied. One limitation of this study, however, was the exclusion of 38 subjects who did not adequately complete the questionnaire.

In conclusion, nursing professionals working in a general hospital show impaired sleep quality associated with shift work, in addition to age and gender. This impairment negatively affects these individuals' quality of life.
7. Costa G, Sartori S, Akerstedt T. Influence of flexibility and variability of working hours on health and well-being. Chronobiol Int. 2006;23(6):1125-37. DOI:10.1080/07420520601087491

8. Drake CL, Roehers T, Richardson G, Walsh JK, Roth T. Shift work sleep disorder: prevalence and consequences beyond that of symptomatic day workers. Sleep. 2004;27(8):1453-62.

9. Ferrara M, De Gennaro L. How much sleep do we need? Sleep Med Rev. 2001;5(2):155-79. DOI:10.1053/smrv.2000.0138

10. Fleck MPA, Louzada S, Xavier M, Chachamovich E, Vieira G, Santos L, et al. Aplicação da versão em português do instrumento abreviado de avaliação da qualidade de vida "WHOQOLbref". Rev Saude Publica. 2000;34(2):178-83. DOI:10.1590/S0034-89102000000200012

11. Lautert L, Chaves EHB, Moura GMSS. O estresse na atividade gerencial do enfermeiro. Rev Panam Salud Publica. 1999;6(6):415-25. DOI:10.1590/S1020-49891999001100007

12. Mehrdad R, Haghighi KS, Esfahani AH. Sleep quality of professional firefighters. Int J Prev Med. 2013;4(9):1095-100. 
13. Moreno CRC, Fischer FM, Rotenberg L. A saúde do trabalhador na sociedade 24 horas. Sao Paulo Perspec. 2003;17(1):34-46. DOI:10.1590/S0102-88392003000100005

14. Müller MR, Guimarães SS. Impacto dos transtornos do sono sobre o funcionamento diário e a qualidade de vida. Estud Psicol (Campinas). 2007;24(4):519-28. DOI:10.1590/S0103-166X2007000400011

15. Oler FG, Jesus AF, Barboza DB, Domingos NAM. Arq Cienc Saude. 2005;12(2):102-10.

16. Oliveira BHD, Yassuda MS, Cupertino APFB, Neri AL. Relações entre padrão do sono, saúde percebida e variáveis socioeconômicas em uma amostra de idosos residentes na comunidade: Estudo PENSA. Cienc Saude Coletiva. 2010;15(3):851-60. DOI:10.1590/S1413-81232010000300028

17. Pereira EF, Teixeira CS, Kothe F, Díaz Merino EAD, Daronco LSE. Percepção de qualidade do sono e da qualidade de vida de músicos de orquestra. Rev Psiquiatr Clin. 2010;37(2):48-51. DOI:10.1590/S0101-60832010000200003

18. Rios KA, Barbosa DA, Belasco AGS. Evaluation of quality of life and depression in nursing technicians and nursing assistants. Rev Latino-Am Enferm. 2010;18(3):413-20. DOI:10.1590/S0104-11692010000300017

19. Rocha MCP, De Martino MMF. Stress and sleep quality of nurses working different hospital shifts. Rev EsC Enferm USP. 2010;44(2):280-6. DOI:10.1590/S0080-62342010000200006
20. Schmidt DRC, Dantas RAS. Qualidade de vida no trabalho de profissionais de enfermagem, atuantes em unidades do bloco cirúrgico, sob a ótica da satisfação. Rev Latino-Am Enferm. 2006;14(1):54-60. DOI:10.1590/S0104-11692006000100008

21. Seidl EMF, Zannon CMLC. Qualidade de vida e saúde: aspectos conceituais e metodológicos. Cad Saude Publica. 2004;20(2):580-8. DOI:10.1590/S0102-311X2004000200027

22. Shao MF, Chou YC, Yeh MY, Tzeng WC. Sleep quality and quality of life in female shiftworking nurses. J Adv Nurs. 2010;66(7):1565-72. DOI:10.1111/j.1365-2648.2010.05300.x

23. Silva AA, Rotenberg L, Fischer FM. Jornadas de trabalho na enfermagem: entre necessidades individuais e condições de trabalho.

Rev Saude Publica. 2011;45(6):1117-26. DOI:10.1590/S0034-89102011000600014

24. The WHOQOL Group. The World Health Organization quality of life assessment (WHOQOL): development and general psychometric properties. Soc Sci Med. 1998;46(12):1569-85. DOI:10.1016/S0277-9536(98)00009-4

25. Triolo PK. Occupational health hazards of hospital staff nurses. Part I: overview and psychosocial stressors. AAON J. 1989;37(6):232-7.

Article based on the doctoral thesis of Palhares VC, titled: "Qualidade de vida, qualidade do sono e fatores de risco cardiovascular de profissionais de enfermagem em um hospital universitário", presented to Programa de Pós-Graduação em Fisiopatologia em Clínica Médica of the Universidade Estadual Paulista "Júlio de Mesquita Filho", in 2012.

The authors declare no conflict of interest. 